\title{
A regionális tudomány térelméleti és módszertani „iskolája” az Eötvös Loránd Tudományegyetemen
}

\section{Spatial theoretical and methodological "school" of regional science at the Eötvös Loránd University}

\section{JAKOBI ÁKOS}

Nemes Nagy József. Csak ennyit kell mondanunk, és már szinte minden szakmabeli tudja vagy sejti, hogy a regionális tudomány miféle gondolatvilágát tükröző mühely bemutatása következik. A Nemes Nagy-féle iskola immár vélhetően ismert szereplője a hazai regionális tudományi kutatásoknak, mindazonáltal szívesen vállaltam el a TéT azon felkérését, amelyben e kutatói közösség kissé mélyebb bemutatását várták tőlem, hátha újat, többet is megtudhat az olvasó. Szavaim elé kívánkozik, hogy mindezt az érintettség okán csak szubjektív módon tehetem, még az is lehet, hogy egy külső szemlélő mindent másképpen lát.

A korábban is elismert munkát végző tanszék - akkori nevén Regionális Földrajzi Tanszék - élén a kilencvenes évek elején lényeges személyi változás történt, amikor Nemes Nagy Józsefet bízták meg a kollektíva munkájának irányításával. Erre az időre esett az egyetem képzési rendszerének egyik első és a regionális tudomány szempontjából máig is fontosnak mondható - átalakítása, amikor kutatószakos (tehát nem csupán tanári) geográfusképzés is indult az ELTE-n környezetföldrajzi, valamint terület- és településfejlesztő szakiránnyal. Ez utóbbi szakirány képzési tervében a regionális tudomány az első pillanattól helyet kapott, sőt nyilvánvaló, hogy a terület- és településfejlesztő szakemberképzés egyik meghatározó alappillérét, alapkurzusát alkotta. A képzési hálót érintő változások persze nemcsak ebben nyilvánultak meg, de abban is, hogy mindez erős statisztikai és számítástechnikai eszközökkel támogatott tárgyakkal övezve jelent meg, felismerve az elméleti kurzusok mellett a módszertani alapozás szükségességét is. Valahol errefele gyökerezik az „iskola” története. A végzett geográfusok (az elsők 1998-ban) igen hasznosnak mondható tudással érkeztek meg a munkaerőpiacra, az országban akkortájt

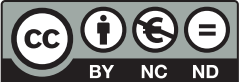


másutt is végző első geográfus-diplomások társaságában, ám némelyek gyorsan felismerték, hogy tudásuk valamelyest más, mint az általános (bár nyilván mindenhol volt specialitás). Az „iskola” első doktoranduszgenerációja az ezredforduló környékén bátran vállalta módszertani ismereteit, amelyekkel a kezdeti konferenciákon alkalmanként nagy érdeklődést keltett. Mindez előbb-utóbb a tanszéki kollektíva munkájának érdeklődési és kutatási fókuszpontjában is egyre nyilvánvalóbb lett, s egyre határozottabbá vált az „iskola” profilja.

Bár a kutatói munka sokszínű témákat érintett az Európai Uniótól a jövedelemegyenlőtlenségeken át az információs társadalomig, a mühely sajátos gondolkodásmódja, pontosabban fogalmazva a tanult ismeretanyag, eszközkészlet és módszertani jártasság mindig érződött az anyagokon. És egy idő után ez már nemcsak tanulás, hanem fejlesztés és kutatás, továbbvitel, továbbgondolkodás és tanítás is lett egyben. Az ezredforduló környékén, illetve a 2000-es évek elején született tanszéki gondozású tankönyvek az amúgy nem különösebben új módszereket a tananyagba integráltan is közzétették (lásd például a Probáld Ferenc által szerkesztett Európa regionális földrajza c. tankönyv egyes fejezeteit), ezzel is segítve a legtágabb szférákban a modern geográfia eszközeinek szélesebb körű megismerését. Sőt, a területi elemzői módszertan rendszerezéseként 2005-ben hiánypótló jelleggel jelent meg a sokak által azóta is gyakran forgatott „Regionális elemzési módszerek” címü könyv, amely egy csapásra ismertté tette a műhely kutatói-elemzői eszköztárát (pontosabban annak egy részét). (Persze nem feledkezhetünk el arról, hogy a területi elemzési módszertan több évtizedes gyökerü már Magyarországon is, gondoljunk csak a Sikos T. Tamás által szerkesztett, 1984-ben megjelentetett „Matematikai és statisztikai módszerek a területi kutatásokban” c. munkára, mindazonáltal a modern oktatási és kutatási gyakorlathoz a fent említett tanszéki mü nagy segítséget jelentett.) A kiadvány sikerét jelzi, hogy az oktatásban azóta is alapmüként szerepel a kötet nemcsak az ELTE-n, de például Miskolcon, Gödöllőn, a Corvinuson vagy éppenséggel Kolozsvárott is, sőt erre alapozva tankönyvek és módszertani segédletek új halmaza is napvilágot látott (esetenként majdhogynem a szó szerinti idézetek szintjén).

No de kanyarodjunk vissza a gyökerekhez! A Nemes Nagy József nevéhez köthető változások, az általános és területi statisztikai ismeretekre, valamint a kvantitatív kultúrára építkező oktatási és kutatási módszerek nem egyik pillanatról a másikra kerültek az érdeklődés középpontjába, vagy legalábbis nem hirtelen váltak oly meghatározóvá a tanszéki munkában (közben ne feledkezzünk el arról sem, hogy a kollégák érdeklődési köre, kutatási szakterülete nem csak erre terjedt ki). Társak is akadtak, például a számítástechnikai alapozásban, amelyben Bernek Ágnes vagy Szegedi Gabriella jelentett nagy segítséget, továbbá minden olyan kolléga, aki értette a statisztikai elemzések nyelvét (például Rédei Mária a demográfiai vizsgálataiban). A „műhely” maga ugyanakkor ezek után kezdett formálódni, amikor egyre meghatározóbbá váltak a módszertani alapokat nemcsak halmozó, bővítő, de érdemi kérdésekben 
fel is használó kutatói elemzések. Lassan formálódni kezdett a műhelyre jellemző kulcsfogalmak köre a Hoover-indextől a súlypont-vizsgálatokon és a területi egyenlőtlenségeken át a regionális GDP-ig vagy a térszerkezeti modellekig. Már ezen felsorolás is jelzi, hogy a kutatói közösség nemcsak a módszertan, de a térelmélet terén is valamelyest hasonló nyelvet beszélt. A mühely másik sajátos jellemzőjeként - véleményem szerint - a térelméleti alapok, a térkategóriák fogalmainak koncepcionális kutatása említhető. Elég, ha Szabó Pál térszerkezet- és régiófogalom-vizsgálataira, Németh Nándor területi fejlődési kutatásaira, a fejlődési tengelyek meghatározására, Tagai Gergelynek a helyzetet, a relatív helyzetet, illetve a gravitációs erőtereket érintő vizsgálataira vagy Jakobi Ákosnak a kibertérbeli térfogalmak értelmezési kísérleteire gondolunk.

A kutatócsapat egyértelműen a regionális tudomány diszciplínájához kötődően tudná meghatározni önmagát, mégis valamiféle sajátos karakterrel, amelyre egyik-másik nemzetközi vagy nagyobb szabású hazai konferencián lehetett felfigyelni. A módszertani és térelméleti témahasználat mögött az „iskola” egyik markáns (egyéni?) vonása sejlik fel. A csoport lényegében a regionális tudomány azon irányzatát követi, amely a térrel magyarázza az egyenlőtlenségeket, ahol a tér van a középpontban, miközben a gazdaság és a társadalom adja a vizsgálati keretet. Még úgy is tűnhet, mintha a tér az elsődleges, míg a gazdasági és társadalmi szféra a másodlagos dimenziót adná, de ezt azért mégse vegyük ily szigorúan. A földrajzi helyzettel, a térkapcsolatokkal vagy a térszerkezeti sajátosságokkal stb. magyarázott társadalmi-gazdasági különbségek, jellegzetességek és folyamatok állandó vizsgálati terepül szolgálnak a csapat számára.

A kis kutatói közösség a közös nyelv és az ambiciózus vezető vonzó hatásainak köszönhetően egyre határozottabb karakterben jelent meg, amihez a csatlakozó kollégák, Kiss János Péter, Szalkai Gábor vagy Lőcsei Hajnalka szakmailag többé-kevésbé hasonló gondolkodásmódja építőleg járult hozzá. Maga az „,iskola” azonban nem kizárólag a tanszék négy fala között működött. Köszönhetően a hasonló érdeklődésnek, a közös nyelvnek (no és persze a doktori iskolai képzési rendszerben nyilvánvaló adminisztratív témavezetői kötődésnek) a térelméleti és módszertani mủhely sokat profitált a közvetlenül nem a közösségben dolgozó, de mégis az „iskolához” kötődő Dusek Tamás vagy Major Klára munkáiból. Mind módszertani, mind térelméleti síkon nagy fejlődést és előrelépést hozott ez az időszak, amikor egymás után jelentek meg a fent említett szerzők tudományos publikációi a műhely gondozásában megjelentetett Regionális Tudományi Tanulmányok kiadványsorozat hasábjain. (Némelyekkel ellentétben én nem érzem badarságnak, ha egy tudományos intézet saját kiadványában és nem csak a népszerü referált folyóiratok stb. oldalain teszi közzé kisebb-nagyobb új szakmai eredményeit; a lényeg az ismeretek terjesztése, a kiadványok legszélesebb körben hozzáférhetővé tétele.) Ennek aztán meg is volt a hatása: a „Nemes Nagy-iskola” módszertani és tér- 
elméleti fogalomhasználati nyelve még szélesebb, sőt távolibb köröket is elért. Csak néhányat említve itt lehetne szót ejteni a VÁTI számos területi elemző munkatársáról, a módszertant a jövedelemkutatásokban felhasználó debreceni Pénzes Jánosról vagy akár az Erdélyben dolgozó Kurkó Ibolyáról, akik az ismeretanyag továbbgondolásával és továbbadásával is foglalkoznak.

Habár a műhely maga nem esik tökéletesen egybe a Nemes Nagy József által vezetett egyetemi tanszék munkatársi körével, mégis a tanszékhez kötődően lehet azt legjobban megragadni. Az oktatás, a szakmai ismeretátadás - úgy vélem - kulcseleme e csoport működésének, és ez nem csupán a publikációk megjelentetésével kivitelezhető. Lényeges momentum volt, amikor a tanszék neve Regionális Földrajziról Regionális Tudományira változott, s ezzel párhuzamban az is, amikor a geográfusképzés újabb reformjaként létrejött a regionális elemző geográfus szakirány is (ha nem is önálló regionális tudományi mesterszak), visszatükrözve a műhely szakmai gondolatvilágát az oktatásban is. (Az említett szakirány legfontosabb számonkérése a „Regionális tudomány - regionális elemzés” szigorlat lényegében pontosan arról szól, amit a műhely képvisel: magas szintű modern területi elemzői eszköztárral kiegészített tiszta és rendszerezett térelméleti alapok ismeretéről.) A tanszék kirajzolódó stílusa a hallgatókat sem hagyta szótlanul, amikor viccesen (vagy talán más indíttatásból?) Számmisztikai Tanszéknek nevezték el azt.

A mühely közössége az évek alatt mit sem vesztett kitartásából, ami az együttműködést és a szakmai párbeszédet illeti, annak ellenére sem, hogy a közösség tagjai, az „iskola” növendékei esetenként más-más munkahelyre sodródtak. A jó kapcsolatok többek között az RKK-val, a VÁTI-val, az NFÜ-vel, az MTA KTI-vel, a Hétfa Kutatóintézettel, illetve a társegyetemekkel viszont részben ennek is köszönhetők. Sőt, a szakmai tartalmú beszélgetések és viták iránti igény további lépéseket is hozott, amikor Németh Nándor kezdeményezésére és Szabó Pál szervezői segítségével 2008 decemberétől a mühely - illetve az ELTE Regionális Tudományi Tanszéke - elindította a Regionális Tudományi Esték sorozatot, amely a szakmai párbeszéd igazi fórumává vált (lásd http://regionalis.elte.hu).

A Regionális Tudományi Estéken közel havi rendszerességgel elhangzó szakmai előadások érdemi szakmai beszélgetésekre adnak lehetőséget. Itt nem egy konferenciáról van szó, ahol 15-20 percben hallgathatjuk meg egyegy előadó prezentációját, és ahol az 5-10 perces vita (vagy inkább csak kommentek és rövid kérdések) után már jön is a következő előadó. Az RTE műhelye fontosnak tartja, hogy egy hosszabb lélegzetvételü előadás után lényegibb vita is legyen az elhangzottakról (amit még az is segít, hogy az előadások mellékleteit gyakorta előzetesen is megismerheti a hallgatóság). Sőt, a vita utáni kötetlen beszélgetés némi zsíros kenyér és bor társaságában még tovább mélyíti a szakmai eszmecserét. Úgy érzem, hogy a TéT korábbi, 2011/1-es számában bemutatott Budapest Kör hallgatóságához hasonlóan itt is igaznak tűnik, hogy egy szakmai közösség életében a kötetlen formába ágyazott, mégis szak- 


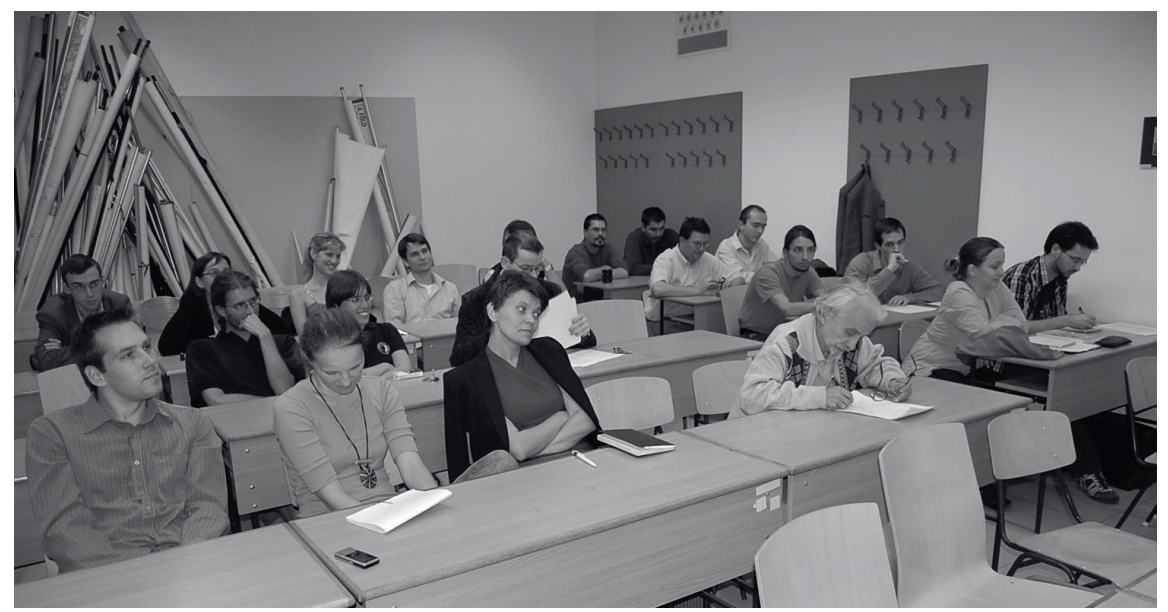

mai mederben tartott közös események valódi jó terepei egymás kutatói gondolatai megismerésének. Még az is előfordul, hogy egy-egy távolabbi téma képviselőjének előadása hozza lázba a meggyökeresedett regionalisták vagy módszertanosok csoportjait. A Regionális Tudományi Esték vitaindító eladásai tehát szerteágazó képet mutatnak, amelyek közül szemezgetve említeném például Czirfusz Márton igazán figyelemre méltó és érdekes vitát kiváltó elöadását, amelyet később a TéT oldalain is megtekinthetett az olvasóközönség „Faktoranalízis, a látszatmegoldás” címmel (lásd a 2010/1-es számot), vagy Izsák Éva teljesen más közelítésű „Posztmodern paradigmaváltás és »térbeli fordulat «?" című vitaindítóját, aki Edward Soja vagy Timár Judit gondolatain elmélkedve tartott előadást a kvalitatív módszertant is szívesen alkalmazó posztmodern területi kutatásokról.

$S$ ha már itt tartunk, a „Nemes Nagy-iskola” a maga térelméleti és módszertani irányultságával alapvetően a kvantitatív irányzatot képviseli, de módszertanilag elismeri a kvalitatív törekvéseket (mondjuk így kommunikál velük), és nyitott a metodikai sokszínűség irányába is. Ezt mi sem jelzi jobban, minthogy épp a tanszék adott otthont a - részben az „iskolához” kötődően működő - MTA RTB Kutatásmódszertani Albizottsága szervezésében idén tavasszal megrendezett kvalitatív módszertani délutánnak.

A módszerek és a térelméleti kutatások továbbra is összekötő kapcsot jelentenek e mühely életében. Ez érhető tetten a Területi Statisztika folyóirat Nemes Nagy Józsefet 60. születésnapja alkalmából köszöntő 2008/3-as számában is, amelyben az ,iskola” számos növendékének tanulmánya olvasható többek között a centrum-periféria-relációk, a legközelebbi szomszéd analízis, a szürkeállomány területi különbségei, vagy a szomszédsági modellezés témaköreiben. Az ifjú generáció - amely az idők során átvette a módszertani alapozó tárgyak oktatását, és továbbviszi, továbbépíti a regionális tudomány elméleti hátterével foglalkozó vizsgálatokat - az újabb kutatásaiban számos 
alkalmazott témát is felvállalt. Az alapokat megtartva mindenki megtalálta a saját tágabb vagy szükebb kutatási terepét a helyi gazdaságfejlesztéstől az Európai Unió regionális politikájának térstruktúrát módosító hatásain át a gazdasági válság területi következményeinek elemzéséig vagy a térinformatikai eszközök és technikák társadalomkutatási alkalmazási lehetőségeinek vizsgálatáig. Úgy tűnik, hogy a közös alapok ellenére, vagy éppen azok mellett a tematikus sokszínűség izgalmas kutatói közösséget formált ki az évek során, de az „iskola” iskola marad, azaz a műhely tovább szándékozik adni a tapasztalatait a tágabb szakmának és a legfiatalabb kutatói generációnak is. 